\title{
Zofia Zierhofferowa jako historyk języka polskiego
}

Zofia Zierhofferowa, mimo braku formalnych stopni i tytułów naukowych, miała ustalony, ,profesorski” status w środowisku językoznawczym. Cieszyła się w tym środowisku niekwestionowanym autorytetem naukowym oraz zasłużoną opinią znakomitej stylistki w mowie i piśmie. Chyba najbardziej jest znana jako współautorka wielkich monografii-syntez Karola Zierhoffera z zakresu adaptacji obcych nazw geograficznych $\mathrm{w}$ języku polskim oraz jako współautorka wzorowej i wzorcowej książki popularnonaukowej - Nazwy miast Wielkopolski (1987). Wprawdzie jej dorobek naukowy sytuuje się głównie w obszarze onomastyki i dotyczy przede wszystkim toponomastyki oraz wspomnianej wyżej adaptacji obcych nazw geograficznych w aspekcie językowym i kulturowym, niemniej jednak Zofia Zierhofferowa legitymuje się też znaczącym dorobkiem historycznojęzykowym, co pozwala na określenie jej mianem historyka języka polskiego, o rozległych kompetencjach badawczych, usytuowanych w różnych obszarach historycznojęzykowych.

Obiektywnie na czoło się tu wysuwa dorobek leksykograficzny Zofii Zierhofferowej. Zatrudniona po studiach polonistycznych, zwieńczonych pracą magisterską (przygotowaną pod kierunkiem prof. Stanisława Urbańczyka) o języku pism Hugona Kołłątaja, w poznańskiej Pracowni Słownika Polszczyzny XVI wieku, przygotowała dla pierwszych dwunastu tomów Stownika polszczyzny XVI wieku wiele autorskich (sygnowanych inicjałami imienia i nazwiska - taką (słusznie) praktykę przyjął słownik) artykułów hasłowych. Z zatrudnieniem w poznańskiej Pracowni Słownika Polszczyzny XVI wieku wiąże się też udział Zofii Zierhofferowej w wielkim przedsięwzięciu edytorskim kierownika Pracowni, prof. Władysława Kuraszkiewicza, a mianowicie w krytycznej naukowej edycji (w prestiżowej serii wznowionej Biblioteki 
Pisarzów Polskich) Postylli Mikołaja Reja w 1965 roku (Zierhofferowa przygotowała dla tego monumentalnego i fundamentalnego wydawnictwa zestawienie różnic językowych miedzy trzecim i czwartym wydaniem Postylli).

W roku 1977 poznańska Pracownia Słownika Polszczyzny XVI wieku została rozwiązana (podobnie zresztą jak inne pracownie „regionalne”, wrocławska i krakowska - pozostała tylko (do dziś) toruńska), a Zofia Zierhofferowa podjęła pracę w Instytucie Języka Polskiego Polskiej Akademii Nauk w Krakowie. Gruntowne i wszechstronne doświadczenie leksykograficzne łączyła już tutaj z onomastyką, uczestnicząc w opracowaniu słownika onomastycznego - wydawanego pod redakcją prof. Kazimierza Rymuta, ówczesnego dyrektora Instytutu Języka Polskiego PAN, słownika Nazwy miejscowe Polski. Historia - Pochodzenie - Zmiany. Jak doskonale wiadomo onomastom, słownik nie jest jeszcze ukończony (wyszło dotąd 12 tomów do litery R). Zofia Zierhofferowa także po przejściu na emeryturę w 1991 roku dostarczała do tego słownika sumiennie zebrany, wzorowo opracowany i zetymologizowany materiał toponomastyczny z całej historycznej Wielkopolski, tzn. z województw poznańskiego i kaliskiego.

Generalnie można powiedzieć, że od podjęcia pracy w Instytucie Języka Polskiego PAN w Krakowie główny nurt jej aktywności badawczej skierował się na obszar onomastyki, czemu zresztą z drugiej strony sprzyjała coraz ściślejsza koncentracja na problematyce onomastycznej jej męża, prof. Karola Zierhoffera.

Jednak w okresie wcześniejszym, zwłaszcza w latach zatrudnienia w poznańskiej Pracowni Słownika Polszczyzny XVI wieku, Zofia Zierhofferowa opublikowała w prestiżowych pismach językoznawczych, takich jak „Język Polski” czy „Polonica”, kilka bezspornie bardzo wartościowych artykułów historycznojęzykowych, głównie leksykologicznych, np. studia o zaimkach sam, siam, sak, siak, o liczbie pojedynczej wyrazu lato w znaczeniu 'annus' czy o różnych osobliwościach leksykalnych naszych największych poetów, takich jak Mickiewicz (tu studium o frazie Lato za latem bieży i podobnych) czy Wyspiański (okież, nieokież). Ma też Zofia Zierhofferowa w swoim dorobku artykuły z obszaru historycznie zorientowanej dialektologii, jak np. o przymiotnikach na -(ej)szy ze szczególnym uwzględnieniem typu rańszy, południejszy. We wszystkich tych pracach dała świadectwo bezspornych kompetencji historycznojęzykowych, w całej rozciągłości potwierdzonych - również i później głosami dyskusyjnymi (w najróżniejszych materiach historycznojęzykowych) na różnego rodzaju sesjach i konferencjach naukowych.

Ale i później, już w okresie badań zdecydowanie zdominowanych problematyką onomastyczną, Zofia Zierhofferowa owocnie łączyła kompetencje 
historycznojęzykowe z onomastycznymi. W szeregu prac wychodziła od apelatywu (góra, kolonia i inne terminy osadnicze), by później poddać analizie oparte na nim nazwy własne. W innych historyczna analiza onomastyczna jest nierozerwalnie związana z historycznojęzykową. Może najlepszego przykładu dostarcza tu bardzo poczytna i pożyteczna książka popularnonaukowa, napisana wspólnie z Karolem Zierhofferem - Nazwy miast Wielkopolski z roku 1987. Zofia Zierhofferowa opatrzyła książkę wstępem lingwistyczno-onomastycznym, w którym bardzo przystępnie (nie rezygnując jednak bynajmniej ze standardów naukowości) wyjaśniła genezę semantycznych i strukturalnych typów nazw miejscowych na tle staropolskiego (ale najwcześniej dającego się zrekonstruować, wczesnośredniowiecznego) słowotwórstwa apelatywnego. Trzeba tu podkreślić fakt, że dla tego okresu (początków polszczyzny jako odrębnego języka słowiańskiego) fakty słowotwórcze nierozerwalnie splatają się z fonetycznymi, zatem by wyjaśnić genezę nazw miejscowych, trzeba dysponować gruntowną i wszechstronną wiedzą o najdawniejszej polszczyźnie - $\mathrm{i}$ to nie wiedzą wyłącznie podręcznikową, operującą gotowymi, nierzadko uproszczonymi schematami przebiegu zmian i procesów językowych, lecz wiedzą gruntownie zinterioryzowaną, która może być odniesiona do rzeczywistego, „nieuładzonego”, filologicznie zaświadczonego materiału językowego. I taką wiedzą dysponowała Zofia Zierhofferowa.

Była - powtórzmy - lingwistką kompletną o profesorskim autorytecie w środowisku językoznawczym. Rozumiała mechanizmy rozwoju języka i na płaszczyźnie apelatywnej, i - oczywiście przede wszystkim - na płaszczyźnie onimicznej. I dlatego miała swoje zdanie - co tylko częściowo znajdowało odzwierciedlenie w jej publikacjach - na temat każdej kwestii językowej, dotyczącej zarówno przeszłości języka, jak i dynamicznie, diachronicznie rozumianej jego współczesności (która w takim ujęciu jest po prostu najnowszą historią języka). 
